\title{
Assessment of Naturally Occurring Radionuclides Accumulation in Palm Oil from Soil
}

\author{
O. B. Olafisoye, O. O. Oguntibeju, and O. A. Osibote
}

\begin{abstract}
Hyper Pure Germanium (HPGe) radiation detector was used to estimate the activity concentration of fifteen soil and palm oil samples collected from the oil palm plantations in the southwestern, southeastern, and south southern states of Nigeria, and the risk assessments was evaluated. The activity concentrations at a soil depth $0-15 \mathrm{~cm}$ ranged from 187.4 to $514.4,2.328$ to 6.571 , and 1.509 to 6.121 $\mathrm{Bq} / \mathrm{kg}$ for ${ }^{40} \mathrm{~K},{ }^{238} \mathrm{U}$, and ${ }^{232} \mathrm{Th}$, respectively. The activity concentrations at a soil depth $15-30 \mathrm{~cm}$ ranged from 163.4 to $3188.8,1.345$ to 9.410 , and 1.476 to $6.275 \mathrm{~Bq} / \mathrm{kg}$ for ${ }^{40} \mathrm{~K},{ }^{238} \mathrm{U}$, and ${ }^{232} \mathrm{Th}$, respectively. The activity concentrations in the palm oil ranged from 122.3 to $968.0,1.240$ to 6.651 , and 1.199 to 8.061 $\mathrm{Bq} / \mathrm{L}$ for ${ }^{40} \mathrm{~K},{ }^{238} \mathrm{U}$, and ${ }^{232} \mathrm{Th}$. For the risk assessments of surface soil samples, the absorbed dose rate (D) ranged from 5.09 to $24.54 \mathrm{nGy} / \mathrm{h}$, while the annual effective dose equivalent (E) ranged from $0.612 \times 10^{-2}$ to $16.49 \times 10^{-2} \mathrm{mSv} / \mathrm{y}$. The radium equivalent, gamma absorbed dose rate, and the annual effective dose rate in the palm oil samples ranged from 9.981 to 88.00 $\mathrm{Bq} / \mathrm{L}, 4.315$ to $46.29 \mathrm{nGy} / \mathrm{h}$, and $0.53 \times 10^{-2}$ to $56.90 \times 10^{-2} \mathrm{mSv} / \mathrm{y}$, respectively. The activity concentrations reported for soil and palm oil samples were lower than the recommended world average values given by UNSCEAR. Hence, the hazard and risk assessments indicated a low radiation risk within the studied areas.
\end{abstract}

Index Terms-Activity concentration, oil palm plantations, pressed -palm fruit oil, risk assessment indices.

\section{INTRODUCTION}

The palm oil plantation is one of the cash producing crops in the south western, south eastern and south southern states of Nigeria supplying palm oil and palm kernel products for local farmers, chemical and allied industries. Vegetable oils or vegetable fats can be referred to as fats extracted from seeds or other parts of the fruit. They are similar to animal fats because they contain a mixture of triglycerides, saturated acids, palmitic acids and polysaturated acids. Palm oil is an edible vegetable oil that is reddish in color. It is extracted from the fleshy mesocarp of the fruit of the oil palm tree, which is indigenous to Africa and Asia. Red virgin palm oil is mechanically pressed from the flesh mesocarp of the oil palm fruit. The red orange color of the oil is derived from its high content of beta-carotene content. It is a highly saturated

Manuscript received June 14, 2021; revised August 18, 2021. This work was sponsored by research fund from Cape Peninsula University of Technology, Cape Town, South Africa).

O. B. Olafisoye is with the Department of Chemistry, Faculty of Applied Sciences, Cape Peninsula University of Technology, Cape Town, South Africa (e-mail: olafisoyeob@gmail.com)

O. O. Oguntibeju is with Department of Biomedical Sciences, Faculty of Health and Wellness, Cape Peninsula University of Technology, Cape Town, South Africa (e-mail: oguntibejuo@cput.ac.za).

O. A Osibote is with the Department of Mathematics and Physics, Faculty of Applied Sciences, Cape Peninsula University of Technology, Cape Town, South Africa (corresponding author; e-mail: osibotea@cput.ac.za). vegetable oil and solid at room temperature. It is commonly used for cooking in parts of Africa, Asia, and South America [1]. It is a useful raw material for culinary purposes and also the food and chemical industry. Palm oil is favorable amongst food scientist due to its low cost and high oxidative ability and nutritional value as it contains a good amount of vitamin $\mathrm{A}$ and $\mathrm{E}$ known to cure various forms of cancer and heart disease [2], [3]. Unrefined, unbleached and un-deodorized virgin palm oil is rich in carotenes, (alpha and beta-carotenes) and lycopene. Palm oil is also used as a raw material in the production of biomass and biofuels and it is used extensively in industry because of its medicinal value and long shelf life [1], [4]-[7]. Nigeria is the third largest producer of palm oil with approximately 2.3 hectares of oil palm plantations under cultivation of small and large-scale processes of palm oil. [8]-[10] Other countries with relatively high yields in the production of palm oil are Thailand, Malaysia, and Indonesia [1].

The assessment of accumulation of radionuclides in pressed palm oil from contaminated soils is essential because the palm oil can be contaminated from other sources other than the soil. Apart from unwholesome agronomical practices, contamination may also arise during the extraction and pressing of the flesh using worn metallic vessels and contaminated water. The oil palm fruit can be contaminated in several ways; one of the ways involves the transfer of the radionuclides through soil and water [11]-[13]. This introduces radionuclides into the food chain and possesses risk to human life if the concentrations are high. The extent and concentration of radioactive materials in a particular region is dependent on geology, climate agronomical farming practices and more [14]-[17]. More of the effects of radiation are manifested in pulmonary and kidney cancer, leukemia and anemia [6], [18], [19]. United Nations Scientific Committee on the Effects of Atomic Radiation (UNSCEAR, 2000) [18], stated that over one-eighth of the annual effective mean dose of radionuclides ingested by man is because of food. The concentrations of naturally occurring radionuclides in palm fruits can be more prominent in the rainy season when accumulation in fruits, shoots, and roots is put into consideration. This could be attributed to direct fallout or runoff from rain [11]-[13].

Radionuclides are accumulated by plants via soil through a process known as translocation from the roots to other parts of the plant [11], [12]. A complex mechanism exist through which radionuclides are transferred from soil/ground water to man and a correlation exists between this depending on the degree of accumulation in different types of plants [20], [21]. Naturally occurring radioactive materials are seen in the environment (air, water, soil, food and even in living things such as plants and animals). Naturally occurring radioactive materials $\left({ }^{40} \mathrm{~K},{ }^{238} \mathrm{U}\right.$ and $\left.{ }^{232} \mathrm{Th}\right)$ are generally persistent in the 
environment because they have long half-life and it takes days and years to completely decay [22]-[25]. It is pertinent to assess these naturally occurring radionuclides concentrations. According to (UNSCEAR, 2000) [10] the global mean dose of natural radiation is estimated to be $2.4 \mathrm{~m}$ $\mathrm{Sv} / \mathrm{y}$ and from artificial or human-made uses $0.8 \mathrm{~m} \mathrm{~Sv} / \mathrm{y}$. Scientist have analyzed the radioactivity concentration in soil and palm oil samples globally and in Nigeria [1, [16], [21]-[23], [25]-[31].

Terrestrial radiation is transferred to water bodies from sediment [32]. United Nations Scientific Committee on the Effects of Atomic Radiation (UNSCEAR 2000) [18] states that more than half of the radiation released on earth is from natural and non-cosmic sources. Amongst the terrestrial radionuclides is uranium, which is prevalent and persistent.

The entry of radionuclides that are present in the terrestrial environment and find entry into the food chain is controlled in the long term by their uptake by plant roots known as the transfer factor, $\mathrm{T}_{\mathrm{f}}$.

This is empirically addressed and modelled in an equation as seen below.

For the radionuclide ' $i$ ' in the edible part of the plant ' $p$ ', it is assumed that $C_{i}^{p}$ (BqL ${ }^{-1}$ dry weight) is linearly related to its concentration in soil within the rooting zone $C_{i}^{S}(15-30 \mathrm{~cm})$ depth. This is to say:

$\mathrm{T}_{\mathrm{f}}=$ (activity concentration of nuclide per liter)/ (activity concentration in dry soil within the rooting zone)
Globally more studies are carried out on the determination of radiation in different areas of the world either as routine checks or baseline studies in order to update previous investigations or investigate fallouts of radionuclides [30], [33]-[36]. Such studies are important for routine and baseline studies and the assessment of the possibility of health risk posed by radionuclides.

The analysis of radionuclides using the Hyper Pure Germanium Detector (HPGe) provided analyzed values of radionuclides and other required data for the calculations of these radionuclides which were compared with standard and permissible values reported by UNSCEAR, 2010 [35] and a comparison with previous studies

Palm plantations are mostly located in the south western region of Nigeria and the palm fruits are cultivated for the production of red palm oil. Such areas are endowed with crystalline basement rocks which are rich in Naturally Occurring Radioactive Materials (NORM) [37], [38]. Hence there is likelihood for soil to plant radionuclide transfer factor enhanced by the physio chemical properties of the soil. Activity concentration and hazard risk assessment were performed to check for risk to human and the environment. A summary (Table I) of a perception into the key findings of some of such investigations indicated that the activity concentration of the naturally occurring radionuclides $\left({ }^{238} \mathrm{U}\right.$, ${ }^{40} \mathrm{~K}$ and ${ }^{232} \mathrm{Th}$ ) and hazard indices were below the permissible limits laid down by regulatory bodies such as IAEA, UNSCEAR and ICRP [22], [35].

TABLE I: PREVIOUS WORKS IN AGREEMENT WITH PRESENT WORK

\begin{tabular}{|c|c|c|c|c|c|}
\hline Reference & Region & Indices Investigated & $\begin{array}{l}\text { Instrument } \\
\text { Used }\end{array}$ & No of Samples & Results obtained \\
\hline $\begin{array}{l}\text { Alausa et } \\
\text { al., } 2017 \\
{[21]}\end{array}$ & $\begin{array}{l}\text { Elere Oil Palm Plantation, } \\
\text { Ibadan, Oyo State, Nigeria }\end{array}$ & $\begin{array}{l}\text { Activity Concentration of NORM. } \\
\text { Transfer Factor from Soil to Palm } \\
\text { Oil. Hazard \& Risk Assessment }\end{array}$ & $\begin{array}{l}\mathrm{Na}(\mathrm{Tl}) \\
\text { Detector }\end{array}$ & $\begin{array}{l}\text { Twenty samples of Soil \& } \\
\text { palm Oil from respective } \\
\text { Palm Oil Trees }\end{array}$ & $\begin{array}{l}\text { Within } \\
\text { Recommended } \\
\text { Limits by } \\
\text { UNSCEAR }\end{array}$ \\
\hline $\begin{array}{l}\text { Augustine } \\
\text { Kolapo, } \\
2019 \text { [39] }\end{array}$ & $\begin{array}{l}\text { Oil Palm Plantation, Oyo } \\
\text { State, Nigeria }\end{array}$ & $\begin{array}{l}\text { Activity Concentration of NORM. } \\
\text { Transfer Factor from Soil to Palm } \\
\text { Oil. Hazard \& Risk Assessment }\end{array}$ & HPGe & $\begin{array}{l}84 \text { soil samples, } 36 \text { food } \\
\text { crop samples, \& } 48 \\
\text { vegetable samples }\end{array}$ & $\begin{array}{l}\text { Within } \\
\text { Recommended } \\
\text { Limits by } \\
\text { UNSCEAR \& ICRP }\end{array}$ \\
\hline $\begin{array}{l}\text { Usikalu et } \\
\text { al, } 2014 \text { [40] }\end{array}$ & $\begin{array}{l}\text { Ewekoro Cement Factory, } \\
\text { Ogun State, Nigeria }\end{array}$ & $\begin{array}{l}\text { Activity Concentration of NORM in } \\
\text { Soil Samples used for Construction. } \\
\text { Hazard \& Risk Assessment }\end{array}$ & HPGe & Sixty Soil Samples & $\begin{array}{l}\text { Within } \\
\text { Recommended } \\
\text { Limits by } \\
\text { UNSCEAR }\end{array}$ \\
\hline $\begin{array}{l}\text { Chad-Umor } \\
\text { en \& Umoh, } \\
2014[41]\end{array}$ & $\begin{array}{l}\text { Soil samples in Abak, } \\
\text { Nigeria }\end{array}$ & $\begin{array}{l}\text { Activity Concentration of NORM in } \\
\text { Soil Samples used for Construction. } \\
\text { Hazard \& Risk Assessment }\end{array}$ & HPGe & Ten soil samples & $\begin{array}{l}\text { Within } \\
\text { Recommended } \\
\text { Limits by } \\
\text { UNSCEAR \& ICRP }\end{array}$ \\
\hline $\begin{array}{l}\text { Oladapo, } \\
2012[42]\end{array}$ & $\begin{array}{l}\text { Wasteland around } \\
\text { Olusosun Dumpsite, Ojota, } \\
\text { Lagos, Nigeria }\end{array}$ & $\begin{array}{l}\text { Activity Concentration of NORM in } \\
\text { Soil Samples used for Construction. } \\
\text { Hazard \& Risk Assessment }\end{array}$ & $\begin{array}{l}\mathrm{Na}(\mathrm{Tl}) \\
\text { Detector }\end{array}$ & Thirty Soil Samples & $\begin{array}{l}\text { Within } \\
\text { Recommended } \\
\text { Limits by } \\
\text { UNSCEAR } \\
\end{array}$ \\
\hline $\begin{array}{l}\text { Jibiri \& } \\
\text { Amakom, } \\
2010[43]\end{array}$ & $\begin{array}{l}\text { Samples of soil waste } \\
\text { stream in the sedimentation } \\
\text { tanks of an oil \& gas } \\
\text { production well site } \\
\text { Petroleum Company in } \\
\text { Warri, Delta, State, Nigeria }\end{array}$ & $\begin{array}{l}\text { Activity Concentration of NORM. } \\
\text { Risk assessment, Cumulative } \\
\text { Cancer Mortality \& Morbidity Risk }\end{array}$ & HPGe & $\begin{array}{l}\text { Samples of soil waste } \\
\text { stream }\end{array}$ & $\begin{array}{l}\text { Within } \\
\text { Recommended } \\
\text { Limits by } \\
\text { UNSCEAR }\end{array}$ \\
\hline $\begin{array}{l}\text { George } \text { et } \\
\text { al., } 2018 \\
{[44]}\end{array}$ & $\begin{array}{l}\text { Samples of soil in a Kaolin } \\
\text { Deposit of the mining field } \\
\text { of Ifonyintedo Town, } \\
\text { Nigeria. }\end{array}$ & $\begin{array}{l}\text { Activity Concentration of NORM in } \\
\text { Soil Samples used for Construction. } \\
\text { Hazard \& Risk Assessment }\end{array}$ & HPGe & Eleven Soil Samples & $\begin{array}{l}\text { Within } \\
\text { Recommended } \\
\text { Limits by } \\
\text { UNSCEAR } \\
\end{array}$ \\
\hline $\begin{array}{l}\text { Olalekan et } \\
\text { al., } 2019 \\
{[45]}\end{array}$ & $\begin{array}{l}\text { A review of soil, rock, } \\
\text { sediment, \& water samples } \\
\text { used in agriculture \& } \\
\text { construction industry in the } \\
\text { northern and southern area } \\
\text { of Nigeria. }\end{array}$ & $\begin{array}{l}\text { Activity Concentration of NORM in } \\
\text { Soil Samples used for Construction. } \\
\text { Hazard \& Risk Assessment }\end{array}$ & HPGe & $\begin{array}{l}\text { A review of over fifty } \\
\text { samples }\end{array}$ & $\begin{array}{l}\text { Within } \\
\text { Recommended } \\
\text { Limits by } \\
\text { UNSCEAR }\end{array}$ \\
\hline
\end{tabular}

This study aims to investigate the concentrations of radionuclides in red palm oil pressed from oil palm fruits 
cultivated on anthropogenically contaminated oil palm plantation soils and evaluates the associated risk it posed. This will generate the baseline data of the level of radiation exposure in the region of study. It is also aimed for routine monitoring for environmental risk assessment in such region. The radionuclides of interest are the naturally occurring radionuclides ${ }^{40} \mathrm{~K} ;{ }^{238} \mathrm{U}$ and ${ }^{232} \mathrm{Th}$ in palm oil pressed from oil palm fruits grown on fifteen independent oil palm plantations soils that may have been polluted anthropogenically by human made activities. as a baseline or monitoring evaluation to ascertain they do not exceed the permissible levels in the environment.

\section{MATERIALS AND METHOD}

\section{A. Geology of Area}

The study area is characterized by few mountains and steep terrains, which are rough with vegetation that is mostly rain forest. Most of the terrain is flat land with rivers. The climate is characterized into two major climates, which are the raining season and the harmattan. The raining season is between March and November and lasts for more than half the year. The soil receives a lot of rainfall all through the year and percolation of ground water into soil is to be considered in the transportation of radionuclides from water into soil and accumulation in the fruit. Hence, the transport of rainfall and the translocation from ground water to soil is of paramount importance [19].

The selected sampling locations (Table II) in states of Nigeria are home to rocks and sediments enclosing valleys and mountains from the south to the western regions of Nigeria. The geology of Nigeria was formed in the Archean and Proterozoic eras. Its province and more than half of the surface is igneous and metamorphic rocks with a crystalline and sedimentary basement. Massive sedimentation was under way in these basins as it returned to its terrestrial conditions within the Pan African mobile belt. The western and southern states lie between eight degrees North latitude and ten degrees south longitude. The terrain is mostly swampy, forest and some marshy areas with various rivers, landscapes, meadows, springs, peninsulas, and islands adorning the regions. The vegetation of the area is mostly forest, shrub land, and wetland, which support the growth of a lot of plantation and cash crops such as the oil palm, rubber, and cocoa tree plantations.

\section{B. Description of Sampling Areas}

Fig. 1 is the map of Nigeria showing all the fifteen sampling points A brief description of some of the major cities and towns is given. Acharu is a town in Dekina local government area of Kogi state. Kogi state is popularly called the confluence state because of the confluence of river Niger and Benue. Flora Shaw coined the name Nigeria out of the river Niger in Lokoja. The Acharu town is blessed with reserves of oil palm. Agbarho is a town in the Ughelli North local government area of Delta state, Nigeria. This area is called the Niger delta and it is affected by oil spillages. In the Niger Delta - oil spillages or leakages are constant features of oil production and have caused physical damage. Benin City is famous for its bronzes and carved works. Deposits of bronze, tin and zinc are scattered around the metropolis.
Agriculture is the main occupation of the locality that provides income and employment for about $75 \%$ of the population.

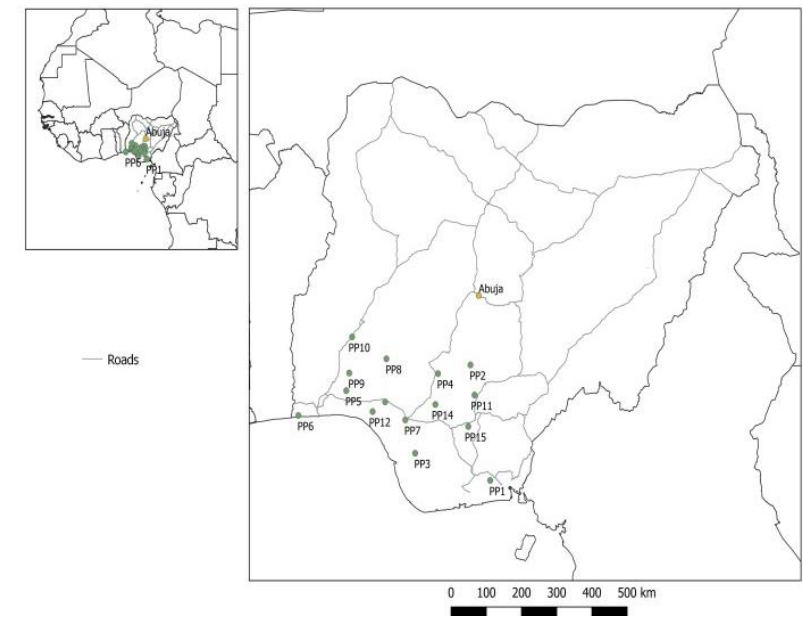

Fig. 1. Map of Nigeria showing sampling locations.

\begin{tabular}{|l|l|l|l|l|}
\hline \multicolumn{5}{|c|}{ TABLE II: SAMPLING LOCATION } \\
\hline Code & Location & Latitude & Longitude & $\begin{array}{c}\text { Elevation above } \\
\text { sea level }(\mathrm{m})\end{array}$ \\
\hline PP1 & Abak & 4.9833 & 7.7833 & 174 \\
\hline PP2 & Acharu & 7.5320 & 7.2792 & 210 \\
\hline PP3 & Agbarho & 5.5833 & 5.8667 & 111 \\
\hline PP4 & Ago-Emokpae & 7.3400 & 6.4500 & 200 \\
\hline PP5 & Apoje & 6.9644 & 4.1064 & 24 \\
\hline PP6 & Badagry & 6.4166 & 2.8833 & 36 \\
\hline PP7 & Benin city & 6.3176 & 5.6145 & 88 \\
\hline PP8 & Igede-Ekiti & 7.6667 & 5.1321 & 576 \\
\hline PP9 & Ikire & 7.3533 & 4.1833 & 207 \\
\hline PP10 & Iresa-apa & 8.1504 & 4.2567 & 118 \\
\hline PP11 & Nsukka & 6.8667 & 7.3833 & 552 \\
\hline PP12 & Okitipupa & 6.5025 & 4.7795 & 305 \\
\hline PP13 & Onishere & 6.7150 & 5.1001 & 68 \\
\hline PP14 & Ubiaja & 6.6597 & 6.3822 & 255 \\
\hline PP15 & Umuabi & 6.1736 & 7.2233 & 221 \\
\hline
\end{tabular}

\section{Sampling Procedure}

Fifteen samples (S1-S15) were collected from topsoil $(0-15 \mathrm{~cm})$ and furthermore from a depth of soil $(15-30 \mathrm{~cm})$ by conventional methods of diagonal systematic sampling using an auger. Diagonal sampling was performed for each sampling point and the samples mixed for homogeneity to give a sample per location. The soil samples was left to dry in a cool airy cupboard for a month. Palm oil samples were taken from the same sampling points as soil samples.Palm oil was collected in $1 \mathrm{~L}$ plastic bottles and the containers were labeled PO1-PO15 with respect to the fifteen sampling points as revealed in Table II. After the drying period for the soils, the previously dried samples were pulverized, crushed, and sieved using a $2 \mathrm{~mm}$ mesh sieve size to obtain soils with definite and homogeneous fine sizes. Sieved samples of soils were dried in an oven set at $100{ }^{\circ} \mathrm{C}$ for 24 hours then transferred to previously cleaned Marinelli beakers. This was properly sealed with paraffin film to prevent any escape of radon gas. Palm oil samples were treated similarly and sealed accordingly. The soil and palm oil samples were kept for a month for the radon gas and its progeny to attain secular equilibrium after which, gamma spectrometry measurements of the samples were carried out. The sampling locations, elevation, and coordinates are listed in Table II. 


\section{Gamma Spectrometry}

The gamma-counting equipment was a Canberra vertical high-purity coaxial germanium (HPGe) crystal detector, model GC2018-7500, series number b 87063 enclosed in a $100 \mathrm{~mm}$ thick lead shield and coupled to a Canberra Multichannel Analysing (MCA) computer system. Calibration of the energy and efficiency of radionuclides was performed with the aid of a well-calibrated standard soil reference standard source supplied by the International Atomic Energy Agency (IAEA), Vienna. The MCA was calibrated to display gamma photopeaks in the energy range of $200-1500 \mathrm{keV}$, this being the energy range covering all the gamma energies of radionuclides of interest. The detector chamber was shielded with three layers of copper, cadmium, and lead of $30 \mathrm{~mm}, 3 \mathrm{~mm}$ and $100 \mathrm{~mm}$ thick, respectively. The photo-peaks observed with regularity in the samples were identified to belong to the natural radioactive decay series headed by ${ }^{238} \mathrm{U}$ and ${ }^{232} \mathrm{Th}$, and a third non-series natural radionuclide, ${ }^{40} \mathrm{~K}$, for a counting time of 36000 seconds.

The activity of the natural radionuclides was calculated using equation 2 .

$$
A s=\frac{C a}{E P r M S}
$$

where

$\mathrm{Ca}$ is the net counting rate of gamma ray (counts per second), $E$ is the detector efficiency of the specific gamma ray, $\operatorname{Pr}$ is the absolute transition probability of gamma decay and $M s$ the mass of the sample $(\mathrm{kg})$.

\section{E. Radium Equivalent $\left(R a_{e q}\right)$}

Radium Equivalent was used to describe the gamma radiation from the varying mixtures of the radionuclides in the soil and is calculated using the relation

$$
\mathrm{Ra}_{\mathrm{eq}}=\mathrm{CRa}+1.43 \mathrm{CTh}+0.077 \mathrm{CK}
$$

where: CRa, CTh and CK are the activity concentrations of ${ }^{226} \mathrm{Ra},{ }^{232} \mathrm{Th}$ and ${ }^{40} \mathrm{~K}$ respectively. The index represents a weighted total of the above-mentioned radionuclides' activity concentrations because of an assumption that states that 1 $\mathrm{Bq} / \mathrm{Kg}$ of ${ }^{226} \mathrm{Ra}, 0.7 \mathrm{~Bq} / \mathrm{Kg}$ of ${ }^{232} \mathrm{Th}$ and $13 \mathrm{~Bq} / \mathrm{Kg}$ of ${ }^{40} \mathrm{~K}$ produce an equal amount of gamma radiation dose [19].

\section{F. Absorbed Dose (D)}

Absorbed dose rate is defined by United Nations Scientific Committee on the Effects of Atomic Radiation and provide the characteristic of the external gamma ray. This was calculated using the equation 4 .

$$
D\left(\frac{n G y}{h}\right)=0.462 C R a+0.604 C T h+0.0417 C K
$$

This is the absorbed dose rate in air outdoor at $1 \mathrm{~m}$ above the ground surface due to specific activity concentrations of ${ }^{238} \mathrm{U},{ }^{232} \mathrm{Th}$ and ${ }^{40} \mathrm{~K}$ (UNSCEAR, 2000).[18]

\section{G. Annual Effective Dose Equivalent (E)}

Annual effective dose equivalent, $\mathrm{E}$ is the parameter to determine the overall effects of the radiation on health due to the absorbed dose rate and calculated by the equation

$$
\mathrm{E}(\mathrm{mSv} / \mathrm{y})=\mathrm{D}(\mathrm{nGy} / \mathrm{h}) \times 8760(\mathrm{~h} / \mathrm{y}) \times 0.2 \times 0.7(\mathrm{~Sv} / \mathrm{Gy}) \times
$$

where the values $0.7 \mathrm{~Sv} / \mathrm{Gy}$ is the conversion coefficient from absorbed dose in the air $1 \mathrm{~m}$ above ground to effective dose received by adults, 8760 is the time taken in hours in a particular year, 0.2 represents the outdoor occupancy factor and is the observed dose rate [19].

\section{H. Excess Lifetime Cancer Risk}

The results of the statistics of cancer in Nigeria revealed that the age normalized occurrence estimate for all intrusive cancers was 66.4 per 100000 men and 130.6 per 100,000 women. Data was based on the Population Based Cancer Registry (IBCR) and the Abuja Population Based Cancer Registry (ABCR) covering a 2 year period which was from 2009-2010 [46]. The term excess life time cancer risk describes the risk of death of cancer in excess of the natural background risk existing from a lifetime of exposure to carcinogenicity. Excess Life Time Cancer Risk (ELCR) was computed from the calculated values of the annual effective Doses as seen in equation [20], [46].

$$
E L C R=A E D E X D_{L} X R_{F}
$$

where $D_{L}$ and $R_{F}$ are the life time duration (70 years) and fatal cancer risk factor for the stochastic effect $\left(0.055 \mathrm{~Sv}^{-1}\right.$ for the general public respectively).

\section{Spectrochemical Analysis}

The prepared samples were analysed by gamma ray spectroscopy with the use of a Hyper Pure Germanium (HPGe) Detector. The counting time for the analysis was 36000 seconds and the soil reference material IAEA-375 was prepared in the same way as the sample and counted in triplicates alongside the sample. The photo peak of the gamma ray for the $\left({ }^{214} \mathrm{Bi}\right) 1764 \mathrm{keV} ;\left({ }^{228} \mathrm{Ac}\right) 911.21 \mathrm{keV} ;\left({ }^{40} \mathrm{~K}\right)$ $1461 \mathrm{keV}$. The Absolute Full Energies were 0.02, 0.001 and 0.04 respectively. These were used to determine the activity of the naturally occurring radionuclides ${ }^{238} \mathrm{U},{ }^{232} \mathrm{Th}$ and ${ }^{40} \mathrm{~K}$. Their percentage emission probabilities corresponded to 14.9, 62.8 and 12.4 respectively The detector was calibrated using the standard source which was a mixture of ${ }^{22} \mathrm{Na},{ }^{57} \mathrm{Co},{ }^{60} \mathrm{Co}$. Spectra analysis was performed using Genie software 2000 developed by CANBERRA. The background contribution was removed by subtracting this from the result of the analysis.

The calculation of the full energy peak was achieved using the equation below [18].

$$
\varepsilon=N / T A B
$$

$N$, is defined as the net count (count per seconds), $T$, is the time (seconds). $A$, is the activity in Becquerel and $B$, is the branching fraction ratio.

The Detection Limit (DL) is the net signal above which a signal can be considered to have been reliably detected. In this study, the Detection Limit (DL) and the Minimum Detectable Activity (MDA) was achieved by modelling the Curies Model formula which presents the background counts, branching ratio, sample mass and detector efficiency. 


$$
\begin{aligned}
& D L=2.71+4.66 \sqrt{N_{B}} \\
& M D A=D L / T E B m
\end{aligned}
$$

$M$ is the mass the sample (kilograms) and $N_{B}$ is the background counts (counts per second).

For the photo peak of the gamma ray $\left({ }^{214} \mathrm{Bi}\right) 1764 \mathrm{keV}$; $\left({ }^{228} \mathrm{Ac}\right) 911.21 \mathrm{keV}$ and $\left({ }^{40} \mathrm{~K}\right) 1461 \mathrm{keV}$, the Detection Limit (DL) the and the Minimum Detectable Activity (MDA), was calculated using equation and as $59.0 \pm 0.3,52 \pm 0.01,77 \pm$ 0.01 and $3.5 \pm 0.1,6.6 \pm 0.1,8.2 \pm 0.2$, respectively [18]

\section{RESUlTS AND DisCUSSION}

Table III presents the concentrations (mean \pm SD) of radionuclides $(\mathrm{Bq} / \mathrm{kg})$ of ${ }^{40} \mathrm{~K},{ }^{238} \mathrm{U}$ and ${ }^{232} \mathrm{Th}$ in soil and palm oil samples collected from the various plantations. An unusual variation is seen in the sampling location. The activity concentrations of ${ }^{40} \mathrm{~K}$ from soil depth of $(0-15 \mathrm{~cm})$ ranged from $187.4-514.4 \mathrm{~Bq} / \mathrm{kg}$ (lowest and highest values were recorded in Benin City and Ikire respectively). The activity concentrations of ${ }^{40} \mathrm{~K}$ soil with depth $(15-30) \mathrm{cm}$ ranged from $163.4-602.7 \mathrm{~Bq} / \mathrm{kg}$ and the minimum and maximum values were recorded at Iresa-apa and Okitipupa plantations respectively. The activity concentrations of ${ }^{238} \mathrm{U}$ from soil depth of $(0-15) \mathrm{cm}$ ranged from $2.328-6.571$ $\mathrm{Bq} / \mathrm{kg}$ and that of soil with depth $(15-30) \mathrm{cm}$ ranged from $1.345-9.410 \mathrm{~Bq} / \mathrm{kg}$. The activity concentrations of ${ }^{232} \mathrm{Th}$ from soil depth of $(0-15 \mathrm{~cm})$ ranged from $1.509-6.121 \mathrm{~Bq} / \mathrm{kg}$ and that of soil with depth $15-30 \mathrm{~cm}$ ranged from 1.476 $6.275 \mathrm{~Bq} / \mathrm{kg}$. Meanwhile, variations of activity concentrations values of radionuclides are better explained by the properties of the soil and accumulation of humus. In the uppermost layer, due to decay and mobility distribution, will require more advanced techniques and studies to determine if an area is safe or unsafe as far as health hazards is concerned. The values for Palm oil were in a similar pattern. Table III represents theActivity Concentration Values for NORM in Soils $(\mathrm{Bq} / \mathrm{kg})$ and Palm Oil $(\mathrm{Bq} / \mathrm{L})$

TABLE III: CONCENTRATION VALUES FOR NORM IN SOILS (BQ/KG) AND PALM OIL (BQ/L)

\begin{tabular}{|l|l|l|l|l|l|l|l|l|l|l|}
\hline \multirow{2}{*}{$\begin{array}{l}\text { Sampling } \\
\text { Location }\end{array}$} & ${ }^{40} \mathrm{~K}$ & \multicolumn{3}{|c|}{${ }^{238} \mathrm{U}$} & ${ }^{232} \mathrm{Th}$ & \multicolumn{3}{|c|}{$\mathrm{K}$} & \multicolumn{3}{c|}{${ }^{238} \mathrm{U}$} & ${ }^{232} \mathrm{Th}$ & ${ }^{40} \mathrm{~K}$ & ${ }^{238} \mathrm{U}$ & \multicolumn{3}{c|}{ Soil Depth $(15-30)$} \\
\hline Abak & $430.9 \pm 0.07$ & $4.905 \pm 0.02$ & $4.929 \pm 0.06$ & $343.2 \pm 0.03$ & $2.467 \pm 0.01$ & $4.935 \pm 0.09$ & $236.1 \pm 0.02$ & $2.677 \pm 0.98$ & $6.881 \pm 0.01$ \\
\hline Acharu & $444.66 \pm 0.01$ & $3.228 \pm 0.07$ & $1.820 \pm 0.01$ & $421.6 \pm 0.01$ & $2.392 \pm 0.02$ & $4.365 \pm 0.01$ & $214.3 \pm 0.01$ & $4.790 \pm 0.34$ & $5.432 \pm 0.02$ \\
\hline Agbarho & $345.0 \pm 0.17$ & $5.176 \pm 0.19$ & $3.148 \pm 0.05$ & $463.2 \pm 0.02$ & $4.877 \pm 0.03$ & $5.041 \pm 0.02$ & $150.4 \pm 0.54$ & $4.790 \pm 0.11$ & $2.156 \pm 0.03$ \\
\hline Ago-Emokpa & $389.7 \pm 0.08$ & $5.778 \pm 0.02$ & $3.426 \pm 0.02$ & $653.4 \pm 0.03$ & $6.575 \pm 0.04$ & $4.770 \pm 0.02$ & $187.5 \pm 0.02$ & $1.705 \pm 0.12$ & $4.243 \pm 0.01$ \\
\hline Apoje & $434.6 \pm 0.01$ & $4.153 \pm 0.04$ & $1.777 \pm 0.09$ & $219.2 \pm 0.01$ & $4.680 \pm 0.05$ & $1.476 \pm 0.13$ & $367.0 \pm 0.03$ & $3.757 \pm 0.45$ & $3.461 \pm 0.24$ \\
\hline Badagry & $193.9 \pm 0.67$ & $3.812 \pm 0.45$ & $2.732 \pm 0.04$ & $211.4 \pm 0.02$ & $1.802 \pm 0.02$ & $4.007 \pm 0.22$ & $122.3 \pm 0.01$ & $2.890 \pm 0.01$ & $3.443 \pm 0.33$ \\
\hline Benin City & $187.4 \pm 0.34$ & $6.173 \pm 0.23$ & $4.816 \pm 0.01$ & $281.1 \pm 0.02$ & $9.410 \pm 0.09$ & $6.275 \pm 0.34$ & $347.2 \pm 0.02$ & $3.924 \pm 0.39$ & $4.311 \pm 0.07$ \\
\hline Igede Ekiti & $411.5 \pm 0.05$ & $5.030 \pm 0.01$ & $6.121 \pm 0.02$ & $467.5 \pm 0.05$ & $6.579 \pm 0.02$ & $4.237 \pm 0.98$ & $327.8 \pm 0.01$ & $2.960 \pm 0.11$ & $6.378 \pm 0.21$ \\
\hline Ikire & $514.4 \pm 0.04$ & $3.471 \pm 0.13$ & $4.237 \pm 0.03$ & $169.0 \pm 0.01$ & $1.726 \pm 0.01$ & $1.829 \pm 0.22$ & $266.7 \pm 0.12$ & $3.192 \pm 0.15$ & $4.109 \pm 0.17$ \\
\hline Iresa Apa & $455.8 \pm 0.03$ & $6.571 \pm 0.23$ & $4.121 \pm 0.09$ & $163.4 \pm 0.03$ & $1.345 \pm 0.03$ & $3.613 \pm 0.12$ & $212.5 \pm 0.15$ & $2.661 \pm 0.41$ & $1.199 \pm 0.03$ \\
\hline Nsukka & $309.2 \pm 0.01$ & $2.328 \pm 0.11$ & $4.760 \pm 0.01$ & $318.8 \pm 0.02$ & $1.789 \pm 0.03$ & $3.500 \pm 0.32$ & $128.2 \pm 0.12$ & $2.475 \pm 0.08$ & $5.249 \pm 0.02$ \\
\hline Okitipupa & $302.7 \pm 0.04$ & $3.189 \pm 0.02$ & $5.988 \pm 0.03$ & $602.7 \pm 0.04$ & $3.788 \pm 0.12$ & $4.239 \pm 0.11$ & $179.4 \pm 0.09$ & $1.240 \pm 0.01$ & $8.060 \pm 0.01$ \\
\hline Onishere & $405.5 \pm 0.08$ & $5.462 \pm 0.11$ & $3.855 \pm 0.21$ & $507.4 \pm 0.05$ & $5.775 \pm 0.99$ & $5.472 \pm 0.01$ & $968.0 \pm 0.02$ & $6.030 \pm 0.02$ & $5.200 \pm 0.01$ \\
\hline Ubiaja & $458.5 \pm 0.01$ & $3.106 \pm 0.03$ & $5.476 \pm 0.02$ & $451.7 \pm 0.02$ & $5.064 \pm 0.34$ & $2.343 \pm 0.01$ & $229.8 \pm 0.02$ & $1.996 \pm 0.01$ & $5.042 \pm 0.02$ \\
\hline Umuabi & $475.6 \pm 0.03$ & $2.884 \pm 0.01$ & $1.509 \pm 0.02$ & $281.3 \pm 0.01$ & $2.327 \pm 0.15$ & $4.264 \pm 0.02$ & $238.6 \pm 0.01$ & $6.651 \pm 0.03$ & $1.509 \pm 0.01$ \\
\hline
\end{tabular}

\begin{tabular}{|c|c|c|c|c|c|c|c|c|c|}
\hline \multirow[t]{2}{*}{$\begin{array}{l}\text { Sampling } \\
\text { Location }\end{array}$} & $\begin{array}{l}\mathrm{Ra}_{(\mathrm{eq})} \\
(\mathrm{Bq} / \mathrm{kg})\end{array}$ & $\mathrm{D}(\mathrm{nGy} / \mathrm{h})$ & $\begin{array}{l}\mathrm{E}(\mathrm{mSv} / \mathrm{y}) \\
\left(\times 10^{-2}\right)\end{array}$ & $\begin{array}{l}\mathrm{Ra}_{(\mathrm{eq})} \\
(\mathrm{Bq} / \mathrm{kg})\end{array}$ & $\mathrm{D}(\mathrm{nGy} / \mathrm{h})$ & $\begin{array}{l}\mathrm{E}(\mathrm{mSv} / \mathrm{y}) \\
\left(\times 10^{-2}\right)\end{array}$ & $\begin{array}{l}\mathrm{Ra}_{(\mathrm{eq})} \\
(\mathrm{Bq} / \mathrm{kg})\end{array}$ & $\mathrm{D}(\mathrm{nGy} / \mathrm{h})$ & $\begin{array}{l}\mathrm{E} \\
(\mathrm{mSv} / \mathrm{y}) \\
\left(\times 10^{-2}\right)\end{array}$ \\
\hline & \multicolumn{3}{|c|}{ Soil Depth (0-15) } & \multicolumn{3}{|c|}{ Soil Depth (15-30) } & \multicolumn{3}{|c|}{ Palm Oil } \\
\hline Acharu & 38.07 & 18.54 & 2.25 & 41.10 & 21.32 & 2.59 & 29.06 & 14.43 & 1.77 \\
\hline Agbarho & 36.25 & 21.12 & 2.56 & 47.76 & 24.61 & 2.99 & 19.45 & 9.787 & 1.20 \\
\hline Ago-Emokpae & 40.69 & 20.99 & 2.55 & 63.71 & 38.17 & 4.63 & 22.22 & 11.17 & 1.44 \\
\hline Apoje & 40.15 & 21.11 & 2.56 & 23.67 & 12.20 & 1.48 & 36.97 & 18.18 & 2.23 \\
\hline Badagry & 22.65 & 11.50 & 1.40 & 23.81 & 12.07 & 1.46 & 17.23 & 8.514 & 1.05 \\
\hline Benin City & 27.49 & 13.58 & 1.65 & 40.03 & 19.86 & 2.41 & 36.82 & 18.90 & 2.23 \\
\hline Igede Ekiti & 45.47 & 23.18 & 2.81 & 12.64 & 5.60 & 0.68 & 37.32 & 18.90 & 2.23 \\
\hline Ikire & 49.14 & 23.17 & 2.81 & 17.36 & 8.97 & 1.08 & 29.61 & 15.08 & 1.86 \\
\hline Iresa Apa & 47.56 & 24.54 & 2.98 & 19.09 & 9.62 & 1.17 & 20.74 & 10.81 & 1.33 \\
\hline Nsukka & 37.19 & 16.85 & 2.04 & 252.27 & 135.88 & 16.49 & 9.981 & 4.315 & 0.53 \\
\hline Okitipupa & 11.75 & 5.09 & 0.62 & 56.26 & 29.44 & 3.57 & 26.58 & 12.92 & 1.60 \\
\hline Onishere & 42.20 & 21.76 & 2.64 & 52.67 & 27.14 & 3.29 & 88.00 & 46.29 & 56.9 \\
\hline Ubiaja & 46.25 & 23.87 & 2.90 & 43.20 & 22.60 & 2.74 & 26.90 & 13.55 & 1.67 \\
\hline Umuabi & 41.66 & 22.07 & 2.68 & 30.09 & 5.39 & 6.54 & 27.18 & 13.93 & 1.71 \\
\hline
\end{tabular}

TABLE IV: VALUES FOR RA, D, \& E IN SOILS AND PALM OIL

Risk assessment indices can be used in the calculation of radionuclide dose in soils and palm oil. Table IV represents the risk assessment results for soil and palm oil obtained in the present study. The results showed the calculated values for Absorbed Dose Rates, Radium Equivalent Activities and Annual Effective Dose Rates for the naturally occurring radionuclides in soils and palm oil respectively. The absorbed dose rate lies in the range of $5.09 \mathrm{nGy} / \mathrm{h}$ and $24.54 \mathrm{nGy} / \mathrm{h}$ in surface soils. The absorbed dose rate lies in the range of 5.09 $\mathrm{nGy} / \mathrm{h}$ in Okitipupa and $24.54 \mathrm{nGy} / \mathrm{h}$ in Iresa -apa in surface soils $(0-15 \mathrm{~cm})$ and $5.39 \mathrm{nGy} / \mathrm{h}-135.88 \mathrm{nGy} / \mathrm{h}$ in Umuabi and Nsukka at depth $15-30 \mathrm{~cm}$. The Annual Effective Dose equivalent was found to vary from $0.62 \times 10^{-2} \mathrm{mSv} / \mathrm{y}$ to 2.98 $\times 10^{-2} \mathrm{mSv} / \mathrm{y}(0-15 \mathrm{~cm})$ and these values were observed in 
Okitipupa and Iresa-apa sampling locations in surface soils. The Annual Effective Dose equivalent was found to vary from $0.68 \times 10^{-2} \mathrm{mSv} / \mathrm{y}$ to $16.49 \times 10^{-2} \mathrm{mSv} / \mathrm{y}(15-30 \mathrm{~cm})$ and these values were observed in Igede Ekiti and Nsukka sampling locations at depth $15-30 \mathrm{~cm}$. The Radium equivalent values ranged between 11.75 to $49.14(\mathrm{~Bq} / \mathrm{kg})$ in surface soils and these values were recorded in Okitipupa and Ikire plantations.

The Radium equivalent values ranged between 12.64 to $252.27(\mathrm{~Bq} / \mathrm{kg})$ at soil depth $15-30 \mathrm{~cm}$ and these values were recorded in Okitipupa and Ikire plantations. The values were lesser than the worldwide values. The results in Table IV reveal that the Annual Effective Dose equivalent in soils was found to vary between $0.612 \times 10^{-2} \mathrm{mSv} / \mathrm{y}$ to $16.49 \times 10^{-2}$ $\mathrm{mSv} / \mathrm{y} . \mathrm{Ra}_{\mathrm{eq}}, \mathrm{D}$ and $\mathrm{E}$ values in palm oils were in the range of 9.981-88.00 Bq/L, 4.315-46.29 $\mathrm{nGy} / \mathrm{h}$ and $0.53 \times 10^{-2}-56.90$ $\times 10^{-2} \mathrm{mSv} / \mathrm{y}$ respectively. The estimated average value of Radium equivalent $\left(\mathrm{Ra}_{\mathrm{eq}}\right)$ in soils and palm oils were lower than the recommended value of $370 \mathrm{~Bq} / \mathrm{kg}$ (UNSCEAR, 2010).[19] The gamma absorbed dose rates (D) in air in the present study were lower than the worldwide average limit value. The values for the Annual Effective Dose Rates (E) followed a similar trend. It was observed that decrease in these values was attributed to rainfall. Transport by rainfall is expectantly high due to changes in the elevation of the region. Radionuclides may be transported to new regions and values varied amongst different sampling locations due to the geographic structures, degree of rainfall and elevations of the region. Regions receiving higher degree of fertilizers, pre planting and post planting activities also contributed significantly to the level of radionuclide in the area. Values were generally lower than the global average limit value.

Table $\mathrm{V}$ show that the Transfer factor $\left(\mathrm{T}_{\mathrm{f}}\right)$ in the pressed all palm oil was a little greater than unity/very close to unity.

TABLE V: TF AND AEDE VALUES FOR NORM IN SOIL AND PALM OIL

\begin{tabular}{|c|c|c|c|c|c|c|}
\hline & \multicolumn{3}{|c|}{ Transfer factor } & \multicolumn{3}{c|}{ Excess Life Time Cancer Risk } \\
\hline \multirow{2}{*}{$\begin{array}{c}\text { Sampling } \\
\text { Location }\end{array}$} & ${ }^{40} \mathrm{~K}$ & ${ }^{238} \mathrm{U}$ & ${ }^{232} \mathrm{Th}$ & \multicolumn{3}{c|}{ AEDE } \\
\cline { 2 - 8 } & \multicolumn{3}{|c|}{ Soil Depth $(15-30 \mathrm{~cm})$} & $\begin{array}{c}\text { Soil } \\
\text { Depth } \\
(0-15 \\
\mathrm{cm})\end{array}$ & $\begin{array}{c}\text { Soil } \\
\text { Depth } \\
(15-30 \\
\mathrm{cm})\end{array}$ & Palm \\
Oil \\
\hline Abak & 0.688 & 1.085 & 1.394 & 0.1086 & 0.0947 & 0.0720 \\
\hline Acharu & 0.508 & 2.003 & 1.244 & 0.0866 & 0.0997 & 0.0682 \\
\hline Agbarho & 0.325 & 0.982 & 0.428 & 0.0986 & 0.1151 & 0.0462 \\
\hline Ago-Emokpae & 0.287 & 0.259 & 0.890 & 0.0982 & 0.1783 & 0.0554 \\
\hline Apoje & 1.674 & 0.803 & 2.345 & 0.0986 & 0.0569 & 0.0859 \\
\hline Badagry & 0.579 & 1.604 & 0.859 & 0.0539 & 0.0562 & 0.0404 \\
\hline Benin City & 1.235 & 0.417 & 0.687 & 0.0635 & 0.0928 & 0.0859 \\
\hline Igede Ekiti & 3.278 & 0.450 & 1.474 & 0.1082 & 0.0262 & 0.0859 \\
\hline Ikire & 1.578 & 1.849 & 2.247 & 0.1082 & 0.0416 & 0.0716 \\
\hline Iresa Apa & 1.301 & 1.978 & 0.332 & 0.1147 & 0.0451 & 0.0513 \\
\hline Nsukka & 0.031 & 1.384 & 1.500 & 0.0785 & 0.6349 & 0.0204 \\
\hline Okitipupa & 1.794 & 0.327 & 1.901 & 0.0239 & 0.1375 & 0.0616 \\
\hline Onishere & 1.908 & 1.044 & 0.950 & 0.0264 & 0.1267 & 2.1907 \\
\hline Ubiaja & 0.509 & 0.394 & 2.152 & 0.1117 & 0.1055 & 0.0643 \\
\hline Umuabi & 0.848 & 2.858 & 0.354 & 0.1032 & 0.2518 & 0.0658 \\
\hline
\end{tabular}

This is an indication of low concentration of NORM from soil to pressed palm oil. Factors responsible include rhizospheres and bioavailability of NORM supported by soil factors and pore size of soils [47]. Rhizospheres can be defined as the section or area around the plant root. Environmental scientists define bioavailability of metals in soil solution as the concentration of that particular metal or compound that is accessible for the plant or organism. For uptake by plants, bioavailability is related to the abundance of nutrients or contaminants such as heavy metals and trace metals, persistent organic pollutants, soil water, soil organic matter, oxygen in soils and water available for plant uptake [48]. Risk assessment can also be determined by the bioavailability of such elements in soils and factors, which influence the uptake. These factors include $\mathrm{pH}$, cation exchange capacity, soil size and texture, soil organic matter, sorption, diffusion and fractions of the soils. The bioavailability of the metals and radionuclides from soil to the edible part of the plant also depends on the competing ions [49]-[53].

\section{CONCLUSION}

All the naturally occurring radionuclides were detected in all samples of the soil and palm oil on the oil palm plantation, but they did not exceed the recommended guidance levels for the ingestion of radionuclides in food. The concentration of ${ }^{40} \mathrm{~K}$ was found to be high in comparison to other radionuclides due to transfer from soils and high transfer ratio. Potassium is found readily in soils especially due to preplanting and post planting operations and the use of pesticides and phosphate fertilizer. In addition, soil characteristics may favor its mobilization and translocation into plant tissues of a micronutrient. However, radioactive potassium, ${ }^{40} \mathrm{~K}$ concentration must be monitored closely as it transports and translocate to fruits through roots/shoot. The radionuclide ${ }^{40} \mathrm{~K}$ is regulated by the human body. The high concentration of potassium in soil samples may be due to the tiny potassium ions trapped inside the clay particle composition of the soil attributed to the crystalline forces that hold these potassium ions uptake [54].

\section{CONFLICT OF INTEREST}

The authors declare no conflict of interest.

\section{AUTHOR CONTRIBUTIONS}

Olafisoye OB performed data collection, the experiment, and data analysis, and wrote the first draft of the manuscript. Oguntibeju O.O and Osibote OA conceptualized the research, supervised the study and edited the manuscript.

\section{REFERENCES}

[1] V. Varsha, L. P. Stuart, N. J. Clinton, and J. S. Sharon, "The impacts of oil palm on recent deforestation and biodiversity," PLOS ONE, vol. 11, no. 7, pp. 1-19, 2016.

[2] R. Loganathan, K. M. Subramaniam, A. K. Radhakrishnan, and Y. Choo, "Health-promoting effects of red palm oil: evidence from animal and human studies," Nutr. Rev., vol. 75, 2017, pp. 98-113, doi:10.1093/nutrit/nuw054.

[3] C. Y. May and K. Nesaretnam, "Highlight article research advancements in palm oil nutrition Ã," Eur. J. Lipid Sci. Technollogy, vol. 116, 2014, pp. 1301-1315, doi:10.1002/ejlt.201400076.

[4] O. B. Imoisi, G. E. Ilori, and I. E. J. Agho, "Palm oil, its nutritional and health implications (a review)," Journal Applied Science Environmental Management, vol. 19, no. 1, pp. 127-127, 2015.

[5] S. Chawla, S. Saxena, E. B. Division, A. Sciences, and L. Road, "Red palm oil - Health benefits and their molecular executors,' International Journal of Bioassays, vol. 2, no. 09, pp. 1223-1231, 2013.

[6] O. B. Olafisoye, O. O. Oguntibeju, and O. A. Osibote, "Trace elements and radionuclides in palm oil, soil, water, and leaves from oil palm plantations: A review," Critical Reviews in Food Science and Nutrition, vol. 57, no. 7, pp. 1295-1315, 2017. 
[7] E. S. Joel et al., "Investigation of natural environmental radioactivity concentration in soil of coastaline area of Ado-Odo/Ota Nigeria and its radiological implications," Scientific Reports, vol. 9, no. 1, pp. 1-8, 2019.

[8] European Commission, "Study on the environmental impact of palm oil consumption and on existing sustainability standards," 2018

[9] A. Baudoin, P. Bosc, and P. Levang, "Review of the diversity of palm oil production systems in Indonesia," 2017.

[10] E. M. Ordway, R. L. Naylor, R. N. Nkongho, and E. F. Lambin, "Oil palm expansion and deforestation in Southwest Cameroon associated with proliferation of informal mills," Nat. Commun., 2015, pp. 1-11, doi:10.1038/s41467-018-07915-2.

[11] N. R Eugenio, M. McLaughlin, and D. Pennock, Soil Pollution, 2018.

[12] IAEA, Handbook of Parameter Values for the Prediction of Radionuclide Transfer in Terrestrial and Fre3hwater, 2010.

[13] IAEA, Modelling the Transfer of Radionuclides to Fruit Report of the Fruits Working Group, 2003.

[14] C. Papastefanou, "Radioactivity of tobacco leaves and radiation dose induced from smoking," International Journal of Environmental Research and Public Health, vol. 6, no. 2, pp. 558-567, 2009.

[15] P. Tchokossa, J. B. Olomo, F. A. Balogun, and C. A. Adesanmi, "Radiological study of soils in oil and gas producing areas in Delta state, Nigeria," Radiation Protection Dosimetry, vol. 153, no. 1, pp. $121-126,2013$.

[16] S. Itoh, T. Eguchi, N. Kato, and S. Takahashi, "Radioactive particles in soil, plant, and dust samples after the Fukushima nuclear accident," Soil Science and Plant Nutrition, vol. 60, no. 4, pp. 540-550, 2014.

[17] P. M. Dieguez-Elizondo, T. Gil-Lopez, P. G. O’Donohoe, J. Castejon-Navas, and M. A. Galvez-Huerta, "An analysis of the radioactive contamination due to radon in a granite processing plant and its decontamination by ventilation," Journal of Environmental Radioactivity, vol. 167, pp. 26-35, 2017.

[18] United Nations Scientific Committee on the Effects of Atomic Radiation, Sources and Effects of Ionizing Radiation: Volume I, 2000.

[19] M. Gruca, T. R. Andel, and H. Balslev, "Ritual uses of palms in traditional medicine in sub-Saharan Africa: A review," Journal of Ethnobiology and Ethnomedicine, vol. 10, no. 1, p. 24, 2014.

[20] Y. Chad-Umoren and I. Umoh, "Baseline radionuclide distribution patterns in soil and radiation hazard indices for Abak, Nigeria," Advances in Physics Theories and Applications, vol. 32, pp. 69-80, 2014.

[21] S. K. Alausa, K. Odunaike, and I. A. Adeniji, "Transfer factor of radionuclides from soil-to-palm oil produced from elere palm tree plantation Near Ibadan Oyo State, Nigeria," Nigeria Journal of Pure and Applied Physics, vol. 7, no. 1, pp. 7-12, 2017.

[22] IAEA, "Radiation protection and safety of radiation sources: international basic safety standards general safety: No GSR part 3," IAEA Safety Standards, p. 436, 2014

[23] M. Blundell, "Naturally occurring radioactive materials," in Proc. the American Gas Association, Operating Section, pp. 490-502, 2015.

[24] K. Harlow, "Naturally occurring radioactive materials and the regulatory challenges to the zircon industry," Journal of the Southern African Institute of Mining and Metallurgy, vol. 117, no. 5, pp. 409413, 2017.

[25] K. S. Krane, The Radioactive Decay Law, 1988

[26] M. B. Cooper, Naturally Occurring Radioactive Materials (NORM) in Australian Industries - Review of Current Inventories and Future Generation, 2005.

[27] K. Fujii et al., "Vertical migration of radiocesium and clay mineral composition in five forest soils contaminated by the Fukushima nuclear accident," Soil Science and Plant Nutrition, vol. 60, no. 6, pp. 751-764, 2014.

[28] N. Todorović et al., "Concentrations of 226Ra, 232Th and 40K in industrial kaolinized granite," Journal of Environmental Radioactivity, vol. 168, pp. 10-14, 2017.

[29] A. Durusoy and M. Yildirim, "Determination of radioactivity concentrations in soil samples and dose assessment for Rize Province, Turkey," Journal of Radiation Research and Applied Sciences, vol. 10 no, 4, pp. 348-352, 2017.

[30] K. Ji et al., "Research progress on the biological effects of low-dose radiation in China," Dose-Response, vol. 17, no. 1, pp. 1-16, 2019.

[31] M. Degerlier, "Assessment of natural radioactivity and radiation hazard in volcanic tuff stones used as building and decoration materials in the Cappadocia region, Turkey," Radioprotection, vol. 48, no. 2, pp. 215-229, 2013

[32] B. S. Bajwa, "Assessment of natural radioactivity levels and associated dose rates in soil samples from historical city Panipat, India," Journal of Radiation Research and Applied Sciences, vol. 10, no. 3, 283-288, 2017.
[33] O. O. Adewoyin et al., "Radionuclides proportion and radiological risk assessment of soil samples collected in Covenant University, Ota, Ogun State Nigeria," MethodsX, pp. 1419-1426, 2018.

[34] A. Kumar, S. Kumar, J. Singh, and P. Singh, "Assessment of natural radioactivity levels and associated dose rates in soil samples from historical city Panipat, India," Journal of Radiation Research and Applied Sciences, vol. 10, no. 3, pp. 283-288, 2019.

[35] United Nations Scientific Committee on the Effects of Atomic Radiation. 2010, "Summary of low-dose radiation effects on health," UNSCEAR 2010.

[36] P. Calmon et al., "Quantification of radionuclide transfer in terrestrial and freshwater environments," Journal of Environmental Radioactivity, vol. 100, no. 9, pp. 671-674. 2009.

[37] M. W. Lema et al., "Environmental contamination by radionuclides and heavy metals through the application of phosphate rocksduring farming and mathematical modeling of their impacts to the ecosystem," International Journal of Engineering Research and General Science, vol. 2, no. 4, pp. 852-863, 2014.

[38] FAO/WHO, "JOINT FAO/WHO food standards programme and codex committee on contaminants in foods," 5th Session, The Hague The Netherlands, Codex Alimentarius Commision, vol. 5, no. 1, p. 88 , 2011.

[39] A. Kolapo, "Natural radionuclide transfer from soil to plants in high background areas in Oyo state, Nigeria," Radiation Protection and Environment, vol. 42, no. 3, p. 112, 2019

[40] M. R. Usikalu, M. L. Akinyemi, and J. A. Achuka, "Investigation of radiation levels in soil samples collected from selected locations in Ogun State, Nigeria," IERI Procedia, vol. 9, pp. 156-161, 2014

[41] Y. E. Chad-Umoren and I. J. Umoh, "Baseline radionuclide distribution pattern in soil and radiation hazard indices for Abak, Nigeria," Advances in Physics Theories and Applications, vol. 32, pp. 69-80, 2014.

[42] O. Oladapo, "Assessment of natural radionuclides level in wasteland soils around Olusosun Dumpsite Lagos, Nigeria," IOSR Journal of Applied Physics, vol. 2, no. 3, pp. 38-43, 2012.

[43] N. N. Jibiri and C. M. Amakom, "Radiological assessment of radionuclide contents in soil waste streams from an oil production well of a petroleum development company in Warri, Niger Delta Nigeria," Indoor and Built Environment, vol. 20, no. 2, pp. 246-252, 2011.

[44] T. A. Adagunodo et al., "Radioactivity and radiological hazards from a kaolin mining field in Ifonyintedo, Nigeria," MethodsX, pp. 362-374, 2018

[45] O. Ifayefunmi, V. Kupriyanov, O. Mirzeabasov, and B. Synzynys, "Review of distribution of natural radiation in some parts of Nigeria," Nuclear Science, vol. 4, no. 4, p. 52, 2019.

[46] E. Jedy-Agbaa,, M. P. Curadob, O. Ogunbiyi, E. O., Fabowale, F. Igbinobad, G. Osubord, T. Otue, H. Kumaie, A. Koechlinb, P. Osinubif, P. Dakuma, and W. Blattnerg, "NIH public access," Cancer Epidemiology, vol. 36, no. 5, pp. 1-17, 2013.

[47] S. D. Ebbs, D. J. Brady, and L. V. Kochian, "Role of uranium speciation in the uptake and translocation of uranium by plants," Journal of Experimental Botany, vol. 49, no. 324, pp. 1183-1190, 1998.

[48] S. C. Sheppard, "Review of "handbook of parameter values for the prediction of radionuclide transfer in terrestrial and freshwater environments," Journal of Environmental Radioactivity, vol. 102, no. 2, p. 217,2011

[49] I. Shtangeeva and S. Ayrault, "Phytoextraction of thorium from soil and water media," Water, Air, and Soil Pollution, vol. 154, no. 1-4, pp. 19-35, 2004

[50] S. Ehlken and G. Kirchner, "Environmental processes affecting plant root uptake of radioactive trace elements and variability of transfer factor data: A review," Journal of Environmental Radioactivity, vol. 58, no. $2-3,97-112,2002$

[51] K. Asaduzzaman, M. U. Khandaker, Y. M. Amin, and R. Mahat, "Uptake and distribution of natural radioactivity in rice from soil in north and west part of peninsular malaysia for the estimation of ingestion dose to man," Annals of Nuclear Energy, vol. 76, pp. 85-93, 2015

[52] M. B. Adedokun et al., "Natural radioactivity contents in commonly consumed leafy vegetables cultivated through surface water irrigation in Lagos state, Nigeria," Journal of Radiation Research and Applied Sciences, vol. 12, no. 1, pp. 147-156, 2019

[53] R. L. Njinga, S. A. Jonah, and M. Gomina, "Preliminary investigation of naturally occurring radionuclides in some traditional medicinal plants used in Nigeria," Journal of Radiation Research and Applied Sciences, vol. 8, no. 2, pp. 208-215, 2015.

[54] H. Bian et al., "Multiple organ lesions in a case of contamination with multiple radionuclides after 38 years," Dose-Response, vol. 16, no. 4 pp. 1-7, 2018. 
Copyright $(2022$ by the authors. This is an open access article distributed under the Creative Commons Attribution License which permits unrestricted use, distribution, and reproduction in any medium, provided the original work is properly cited (CC BY 4.0).

Olafisoye Oladunni Bola obtained her PhD degree in chemistry from the Cape Peninsula University of Technology, Cape town South Africa. She is also a staff of the Department of Chemistry, Bowen University Iwo. She has published several articles in journals of repute.

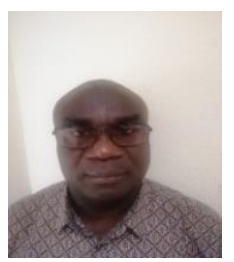

Oluwafemi O. Oguntibeju is a professor of biomedical science and group leader (Phytomedicine \& Phytochemistry Group), Cape Peninsula University of Technology Bellville, South Africa. He has successfully supervised 25 honours' projects, 24 masters and 6 doctoral students and currently supervising 6 doctoral and 6 masters' students. He has mentored three postdoctoral research fellows. He has published over 150 scientific articles in peer-review journals, 20 chapters in books, editor of three books on diabetes, presented over 70 papers at international and national conferences. He is a member of editorial board of various scientific journals and reviews manuscripts for various scientific journals. He has received various awards such as the Gold and Platinum Research Excellence Awards at his current university. In 2015, he received "Award for Excellence" in recognition of his contribution to biomedical research. He is a National Research Foundation (NRF) C-rated researcher. He qualified as a biomedical scientist in June 1992 and holds a Postgraduate Diploma (FIMLS) of the Institute of Medical Laboratory Science, Nigeria in Clinical Biochemistry (1994), MSc degree in Biochemistry from the University of Ibadan (1997), Nigeria and a doctoral degree in Biomedical Science, Central University of Technology, Free State (2005), South Africa.

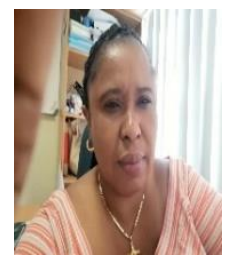

Otolorin Adelaja Osibote obtained her Ph.D (medical physics) from Escola Nacional de Saude Publica (National School of Public Health)-FIOCRUZ, Brazil. She was a postdoctoral research fellow in the Department of Nuclear Energy, Universidade Federa de Pernambuco (Federal University of Pernambuco), Brazil and in the Department of Human Biology (Biomedical Engineering) of University of Cape Town, South Africa. She was a junior research associate of the Abdus Salam International Center for Theoretical Physics from 2002 to 2006. Dr. Osibote assumed a faculty position in the Department of Physics, Olabisi Onabanjo University in 1995 and presently in the Department of Mathematics and Physics, Cape Peninsula University of Technology, South Africa. She has carried out research on several areas including irradiation of foodstuffs, quality assurance in diagnostic radiology, developments of algorithms for automated focusing of a microscope for the detection of tuberculosis and measurement of heavy metals and radioactivity in food and environmental fields. 